\title{
Phosphorus Adsorption of Some Brazilian Soils in Relations to Selected Soil Properties
}

\author{
Valdinar Ferreira Melo ${ }^{*}$, Sandra Cátia Pereira Uchôa ${ }^{1}$, Zachary N. Senwo ${ }^{2 *}$, \\ Ronilson José Pedroso Amorim ${ }^{3}$ \\ ${ }^{1}$ Department of Soil and Agricultural Engineering, Federal University of Roraima, Boa Vista, Brazil \\ ${ }^{2}$ Department of Biological \& Environmental Sciences, Alabama A\&M University, Huntsville, USA \\ ${ }^{3}$ Agronomy, Federal University of Roraima, Boa Vista, Brazil \\ Email: valdinar@yahoo.com.br, ${ }^{*}$ zachary.senwo@aamu.edu
}

Received 3 April 2015; accepted 17 May 2015; published 20 May 2015

Copyright (C) 2015 by authors and Scientific Research Publishing Inc.

This work is licensed under the Creative Commons Attribution International License (CC BY).

http://creativecommons.org/licenses/by/4.0/

c. (i) Open Access

\begin{abstract}
A major nutritional problem to crops grown in highly weathered Brazilian soils is phosphorus (P) deficiencies linked to their low availability and the capacity of the soils to fix $P$ in insoluble forms. Our studies examined factors that might influence $P$ behavior in soils of the Amazon region. This study was conducted to evaluate the maximum phosphate adsorption capacity (MPAC) of the soils developed from mafic rocks (diabase), their parent materials and other factors resulting in the formation of eutrophic soils having A chernozemic horizon associated with Red Nitosols (Alfisol) and Red Latosols (Oxisol) of the Amazonian environment. The MPAC was determined in triplicates as a function of the remnant $P$ values. The different concentrations used to determine the MPAC allowed maximum adsorption values to be reached for all soils. The Latosol (Oxisol) and Nitosol (Alfisol) soils presented higher phosphate adsorption values that were attributed to the oxidic mineralogy and high clay texture while the Chernosol (Mollisol) soils presented the lowest phosphate adsorption values.
\end{abstract}

\section{Keywords}

Amazon Soil, Eutrophic Soils, Oxidic Soils, Phosphate, Alfisol, Oxisol

\section{Introduction}

Due to the climatic variations impacting the Amazon region of Brazil, the Northeast area of Roraima has transitioned from a semi-arid climatic condition to one with high precipitation [1]. The increase in precipitation has

\footnotetext{
*orresponding authors.
}

How to cite this paper: Melo, V.F., Uchôa, S.C.P., Senwo, Z.N. and Amorim, R.J.P. (2015) Phosphorus Adsorption of Some Brazilian Soils in Relations to Selected Soil Properties. Open Journal of Soil Science, 5, 101-109. 
greatly affected the soil's biogeochemical weathering attributes, erosion and deposition processes, thus contributing to the formation of deep, highly weathered soils dominant in kaolinite and oxidic mineralogy [2]. Some areas of the Amazon have soils originated from mafic rocks (diabase), resulting in the formation of Eurtophic Red Nitosol (Haplustalf), Dystrophic Yellow Red Latosol (Xanthic Haplustox), Eutropic Haplic Tb Cambisols, with A chernozem, Orthic black Chernosol (Mollisol) and vertic Orthic Ebanic Cheronosol (Mollisol) soil series [3].

Studies have shown that the soils consist typically of kaolinitic mineralogy and low fertility, with the predominant classes being Yellow Latosols (Oxisol) and Yellow Argisols (Ultisol) [4]-[6]. The indigenous areas of Roraima in general are located where these soils are found and reflect certain aspects of the sustainability and quality of life of the indigenes cultivating the soils for agricultural production. In the Raposa Serra do Sol Indigenous Reserve (approximately 1,747,464 ha); the proportion of soils (approximately 19,900 ha) considered as fertile for sustainable agricultural production is situated on gentle undulating relief and includes diabase soils of the "Pedra Preta" Sill [7].

A major nutritional problem to crops grown in these soils is $\mathrm{P}$ deficiency linked to low available $\mathrm{P}$ content and capacity to fix fertilizer $\mathrm{P}$ in insoluble form. Evaluating the $\mathrm{P}$ availability in these soils is important because soil $\mathrm{P}$ adsorption capacity directly influences plant response to phosphate fertilization of soils. Phosphorus fixation in soils, widely designated as adsorption, is a slow process that can take years to reach a balance and may lead to decrease in P availability. In most Brazilian soils, studies have shown that the major factors influencing soil P adsorption are the clay fractions, mineralogy, amorphous colloid content, $\mathrm{pH}$, exchangeable aluminum and organic matter [8]-[10].

Phosphorus adsorption depends on the nature and quality of sites available on the mineral surfaces and is therefore affected by high clay contents within the same mineralogy [11]. Studies by Ker et al. [9] indicate that the mineralogy, crystal size, and specific surfaces of soils will be more important than the quantity of clay in determining soil's P adsorption capacities [12]-[14]. Bedin et al. [14] state that the presence of large proportions of sesquioxides on clays influences phosphate adsorption and precipitation with iron and aluminum. The objective of this study was to evaluate the maximum P adsorption capacity (MPAC) of the soils developed from mafic rocks (diabase) in northeastern Roraima and its relationships with certain physical, chemical and mineralogical attributes.

\section{Materials and Methods}

The soils used in this study were sampled from a toposequence and consisted of five soil profiles, developed from mafic rocks that form one of the largest mafic rock bodies in North Amazon's "Pedra Preta" Sill. The Maloca do Flechal study areas (Figure 1) is inhabited by the Macuxi Indians and situated in the northeast of the state of Roraima, Brazil. The climate average about $1200 \mathrm{~mm}$ in rainfall, with sunshine duration of 12 hours/day. The region's relief is characterized as undulated with step savannah vegetation and patches of seasonal forest on the East-West transect line.

The fieldwork consisted of opening trenches in a toposequence, collecting the soil samples in each profile soil and describing them according to Santos et al. [15]. Soils were classified based on the Brazilian Soil Classification System manual published by Embrapa [16] and analyzed for chemical properties (Table 1) as described in a soil analysis manual published by Embrapa [17]. The profiles were classified as Eutrophic Red Nitosol (Alfisol)$\mathrm{NVe}$, Tb Eutrophic Haplic Cambisol (Inceptisol)-CXbe; Orthic Ebanic Chernosol (Mollisol)-MEo; vertic Orthic Ebanic Chernosol (Mollisol)-MEov and Distgrophic Yellow Red Latosol (Oxisol)-LVAdf.

The Fe associated with the low crystal minerals in the surface horizons was extracted with ammonium oxalate [18], and the free Fe extracted using dithionite-citrate bicarbonate (DCB) [19]. The Fe content was determined using induced plasma emission spectrometry while the Fe associated with the crystalline minerals was calculated by the difference between the Fe extracted by DCB $\left(\mathrm{Fe}_{\mathrm{d}}\right)$ and the $\mathrm{Fe}$ extracted with oxalate $\left(\mathrm{Fe}_{\mathrm{o}}\right)$. The mineralogy was determined by X-ray diffraction of the clay and silt fraction. From the natural, Fe-free clay fraction, oriented slides were prepared and irradiated in an X-ray diffractometer at sweeping angle $(2 \theta)$ intervals between $2^{\circ}$ and $40^{\circ}$ and a goniometer speed of $2^{\circ}$ in $2 \theta / \mathrm{min}$, using $\mathrm{CuK} \alpha$ radiation with Ni filter [20]. Powdered silt slides were analyzed under the same conditions while the diffraction patterns were interpreted according to Chen [21].

Phosphorus (P) was evaluated as described by Alvarez and Fonseca [22] using $5 \mathrm{~g}$ of fine ground soils mixed with a solution of $\mathrm{CaCl}_{2}\left(0.01 \mathrm{~mol} \cdot \mathrm{L}^{-1}\right)$ containing $50 \mathrm{mg} \cdot \mathrm{L}^{-1} \mathrm{P}$ and shaken for an hour then filtered and the $\mathrm{P}$ 


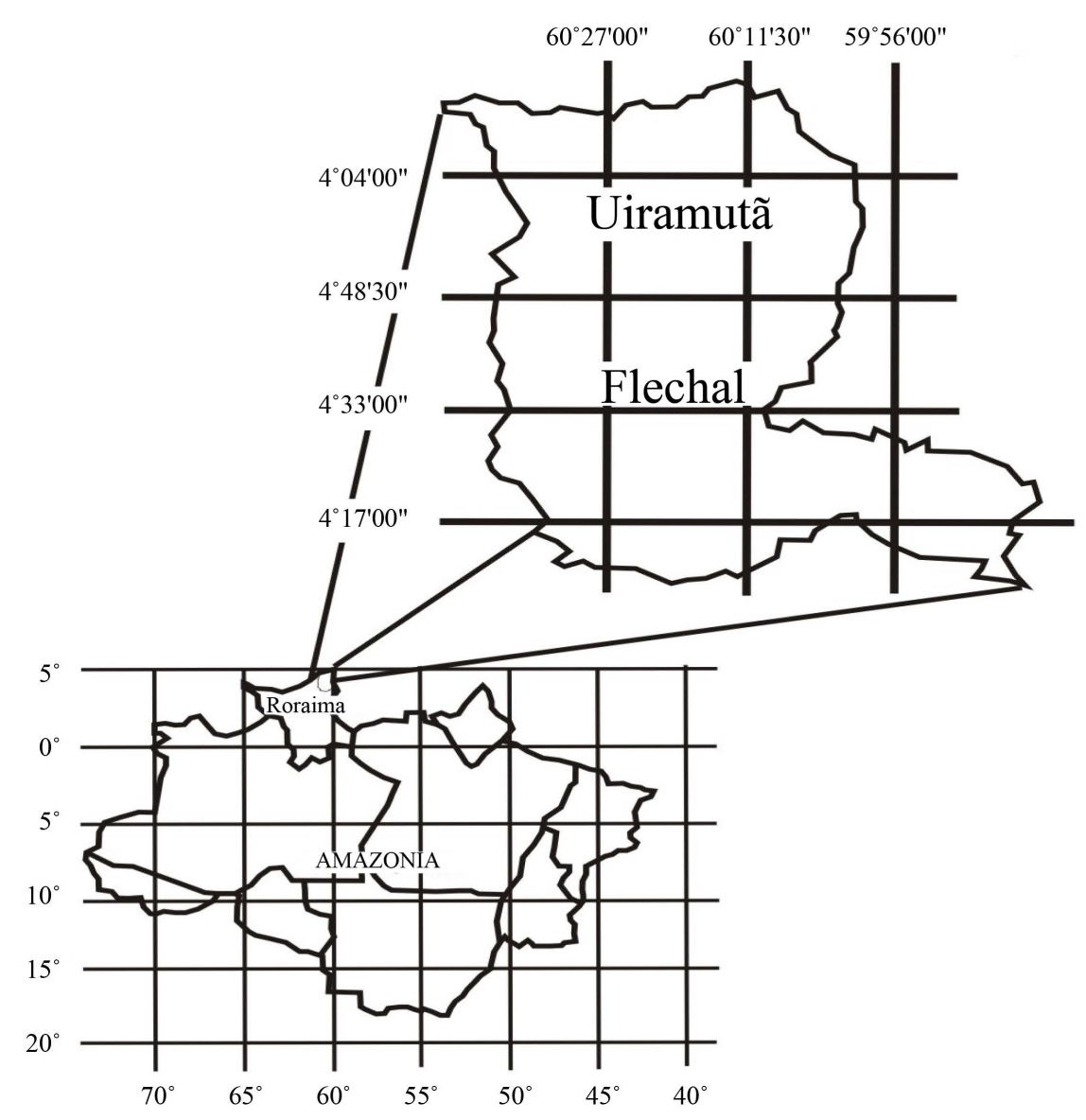

Figure 1. The maloca do flechal study areas.

Table 1. Chemical characteristics of soils studied.

\begin{tabular}{|c|c|c|c|c|c|c|c|c|c|c|c|c|c|}
\hline \multirow{2}{*}{ Soil } & \multirow{2}{*}{ Hor. } & \multirow{2}{*}{$\mathrm{pH}$} & $\mathrm{Ca}^{2+}$ & $\mathrm{Mg}^{2+}$ & $\mathrm{Na}^{+}$ & $\mathrm{K}^{+}$ & $\mathrm{Al}^{3+}$ & $\mathrm{H}+\mathrm{Al}$ & $\mathrm{S}$ & CEC & $\mathrm{V}$ & \multirow{2}{*}{$\begin{array}{l}\mathrm{SOM} \\
\mathrm{g} \cdot \mathrm{kg}^{-1}\end{array}$} & \multirow{2}{*}{$\frac{\mathrm{P}}{\mathrm{mg} \cdot \mathrm{kg}^{-1}}$} \\
\hline & & & \multicolumn{9}{|c|}{ - } & & \\
\hline \multirow{2}{*}{$\mathrm{NVe}$} & $\mathrm{Ap}$ & 5.7 & 2.63 & 2.48 & 0.13 & 0.10 & 0.05 & 6.87 & 5.34 & 12.21 & 43 & 24.6 & 0.96 \\
\hline & Bnit & 5.9 & 1.03 & 0.91 & 0.03 & 0.01 & - & 2.20 & 1.98 & 4.18 & 65 & 9.3 & 0.72 \\
\hline \multirow{2}{*}{ MEo } & Ap & 6.1 & 6.87 & 3.16 & 0.32 & 0.15 & - & 4.34 & 10.50 & 14.84 & 71 & 23.8 & 2.50 \\
\hline & Bnit & 6.2 & 5.80 & 2.62 & 0.04 & 0.05 & 0.05 & 3.57 & 8.51 & 12.08 & 71 & 14.2 & 1.01 \\
\hline \multirow{2}{*}{ CXbe } & Ap & 6.8 & 8.69 & 2.79 & 0.11 & 0.05 & 0.05 & 2.75 & 11.64 & 14.39 & 81 & 15.3 & 1.33 \\
\hline & $\mathrm{Bi}_{2}$ & 7.3 & 9.21 & 0.00 & 0.12 & 0.05 & - & 1.54 & 9.38 & 10.92 & 86 & 9.5 & 1.44 \\
\hline \multirow{2}{*}{ MEov } & Ap & 7.0 & 9.31 & 0.04 & 0.09 & 0.05 & - & 2.53 & 9.35 & 11.88 & 79 & 20.6 & 1.16 \\
\hline & $\mathrm{Bi}_{2}$ & 7.4 & 12.7 & 0.06 & 0.11 & 0.05 & - & 1.43 & 12.92 & 14.35 & 90 & 3.7 & 1.39 \\
\hline \multirow{2}{*}{ CXbe } & Ap & 6.5 & 6.75 & 0.37 & 0.07 & 0.04 & - & 3.24 & 7.23 & 10.63 & 69 & 19.3 & 1.22 \\
\hline & $\mathrm{Bi}_{2}$ & 7.8 & 7.31 & 0.00 & 0.09 & 0.03 & - & 0.71 & 7.43 & 8.14 & 91 & 3.7 & 1.08 \\
\hline \multirow{2}{*}{ LVAd } & A & 5.4 & 0.00 & 0.49 & 0.14 & 0.11 & 0.50 & 6.60 & 0.74 & 7.34 & 10 & 24.6 & 1.48 \\
\hline & $\mathrm{Bw}$ & 4,3 & 0.00 & 0.50 & 0.04 & 0.04 & 0.50 & 8.52 & 0.52 & 9.04 & 06 & 22.5 & 0.53 \\
\hline
\end{tabular}

Hor. = Horizon. 1) $\mathrm{pH}$ in water. 2) $\mathrm{S}=$ sum of bases. $\mathrm{CEC}=$ Cation exchange capacity at $\mathrm{pH}$ 7.0. $\mathrm{V}=$ percentage of saturation by bases; SOM = Soil organic matter. $\mathrm{P}=$ Phosphorus extractable by Mehlich-1. NVe-Red Nitosol. MEo-Orthic Ebanic Chernosol. Cxbe-Tb Eutrophic Haplic Cambisol. MEov-Vertic Orthic Ebanic Chernosol, LVAd-Distrophic Red Yellow Latosol.

concentration using Murphy and Riley [23] procedure. The Langmuir isotherm were obtained by adding $25 \mathrm{~mL}$ $\mathrm{CaCl}_{2}\left(10 \mathrm{~mol} \cdot \mathrm{L}^{-1}\right)$ solution containing $\mathrm{P}$ in doses ranging from 0 to $60 \mathrm{mg} \cdot \mathrm{L}^{-1}$. After 24 hours agitation, the 
samples were centrifuged and the $\mathrm{P}$ in the equilibrium solution was quantified colorimetrically [23].

The data were fitted to the non-linear Langmuir model, relating the concentration of the adsorbed element per adsorption unit (soil) and the concentration of the element in the equilibrium solution (supernatant), and the maximum adsorption capacity calculated. The sorption values of each soil were plotted according to the Langmuir isotherm: $\mathrm{C} /(\mathrm{x} / \mathrm{m})=(1 / \mathrm{Kb})+(\mathrm{C} / \mathrm{b})$. Where $\mathrm{C}$, is equilibrium $\mathrm{P}$ concentration $\left(\mathrm{mg} \cdot \mathrm{L}^{-1}\right), x / m$ is the amount of sorbed $\mathrm{P}\left(\mathrm{mg} \cdot \mathrm{kg}^{-1}\right), m$ and $b$, are the constants related to $\mathrm{P}$ sorption maximum $\left(\mathrm{mg} \cdot \mathrm{kg}^{-1}\right)$ and $K$ is the bonding energy $\left(\mathrm{L} \cdot \mathrm{mg}^{-1}\right)$, respectively. The plot of $\mathrm{C} /(\mathrm{x} / \mathrm{m})$ versus $C$ should give a straight line from which $1 / \mathrm{b}$ (slope) and $K$ (slope or intercept) can be calculated [24]. The Pearson analysis of simple linear correlation using the Statistic program 7.0 between MPAC and some soil characteristics was carried out, and the correlations greater than $95 \%$ were considered significant $(\alpha<0.05)$.

\section{Results and Discussion}

The Fe contents determined from successive extractions using DCB (2), ranged from 29.4 (MEov) to 258.7 $\mathrm{g} \cdot \mathrm{kg}^{-1}$ (LVAdf). The values seemed high and atypical of Roraima [5] [6] and Amazonia soils [25] [26], given that the predominant soils in these environments have iron contents averaging less than $73 \mathrm{~g} \cdot \mathrm{kg}^{-1}$. The LVAdf stood out among the soils studied with lower $\mathrm{Fe}_{\mathrm{o}} / \mathrm{Fe}_{\mathrm{d}}$ ratio indicating the predominance of high crystalline iron oxide.

The soils mineralogical compositions (Table 2) showed the presence of high mineral activities. Illite was common in all the soil horizons but smectite was restricted to soils with the A Chernozem horizon (CXbe and MEov). Kaolinite also occurred generally in most of the profiles, indicating intense weathering with strong lixiviation of bases, low fertility and lower (CEC) especially for LVAdf. The mineralogy of the 2:1 group might have resulted from the geology and climatic variations in the Amazon over geological time. The northeast of Roraima has passed through a recent sub-period of semi-arid climate to the current conditions of greater precipitations [27] [28]. However, this mineralogy contrasts with the data obtained by Vale Júnior [5] and Melo et al. [6] for other Roraima soils.

The $\mathrm{P}$ values varied greatly among the soil profiles and horizons. The highest values were observed in the surface horizons (Table 3), ranging from 19.8 (LVAdf) to $50.2 \mathrm{mg} \cdot \mathrm{L}^{-1}$ (MEo). For the surface horizons, the values ranged from $6.6 \mathrm{mg} \cdot \mathrm{L}^{-1}$ (LVAdf) to 46.9 (MEov) and this could be attributed to the type of clay mineralogy present in the soils. According to Alvarez et al. [29], the soils and horizons analyzed presented low P retention, except for LVAdf, which could be attributed to the highly negative charge on the smectites surfaces of the clays. The high $P$ values in most of the soils could be explained by the striking presence of 2:1 minerals. Alves and Lavorenti [30] worked with Latosols in the state of São Paulo, Brazil and reported the lack of correla-

Table 2. Mineralogical composition of the clay, silt and sand fractions of soils studied.

\begin{tabular}{|c|c|c|c|c|}
\hline Soil & Hor. & Clay & Silt & Sand \\
\hline \multirow{2}{*}{$\mathrm{NVe}$} & Ap & $\mathrm{Ct}, \mathrm{Gt}$ & $\mathrm{Qz}, \mathrm{Ct}, \mathrm{Bt}, \mathrm{Fs}, \mathrm{Ilm}$ & $\mathrm{Qz}, \mathrm{Mi}$ \\
\hline & Bnit & $\mathrm{Ct}, \mathrm{Il}, \mathrm{Gt}$ & Qz, Ct, Bt, Fs, Ilm, Pg & Qz, Mi, \\
\hline \multirow{2}{*}{ MEo } & Ap & $\mathrm{Ct}, \mathrm{Il}, \mathrm{Gt}$ & Qz, Bt, Fs, Px & Qz, Mi \\
\hline & Bnit & $\mathrm{Ct}, \mathrm{Il}, \mathrm{Gt}$ & $\mathrm{Qz}, \mathrm{Ct}, \mathrm{Mi}$ & Qz, Mi \\
\hline \multirow{2}{*}{ CXbe } & Ap & $\mathrm{Ct}, \mathrm{Il} / \mathrm{Mt}, \mathrm{Es}, \mathrm{Gt}$ & Qz, Fs, Ct, Px, Af & Qz, Fs, Pg, Mi \\
\hline & $\mathrm{Bi}_{2}$ & $\mathrm{Ct}, \mathrm{Il}$, Es & $\mathrm{Pg}, \mathrm{Fs}, \mathrm{Qs}, \mathrm{Ct}, \mathrm{Mi}, \mathrm{Af}$ & $\mathrm{Pg}, \mathrm{Qz}, \mathrm{Fs}, \mathrm{Mi}, \mathrm{Mg}, \mathrm{Cn}$ \\
\hline \multirow{2}{*}{ MEov } & Ap & $\mathrm{Ct}$, Il, Es & Fs, Pg, Qz, Ct, Mi, Af & Qz, Pg, Af, Fs \\
\hline & $\mathrm{Bi}_{2}$ & Es, Ct, Il & $\mathrm{Ac}, \mathrm{Cl}, \mathrm{Mi}, \mathrm{Fs}$ & Qz, Pg, Fs, Cn \\
\hline \multirow{2}{*}{ CXbe } & Ap & $\mathrm{Ct}, \mathrm{Il}, \mathrm{Gt}$ & $\mathrm{Ct}, \mathrm{Qz}, \mathrm{Zl}, \mathrm{Pg}$ & $\mathrm{Qz}, \mathrm{Fs}, \mathrm{Ru}$ \\
\hline & $\mathrm{Bi}_{2}$ & $\mathrm{Ct}, \mathrm{Il}, \mathrm{Gt}$ & $\mathrm{Ct}, \mathrm{Qz}, \mathrm{Hb}, \mathrm{Bt}$ & Qz \\
\hline \multirow{2}{*}{ LVAd } & Ap & $\mathrm{Gb}, \mathrm{Ct}, \mathrm{Il}, \mathrm{Gt}$ & $\mathrm{Qz}, \mathrm{Ct}, \mathrm{Gb}, \mathrm{Ru}, \mathrm{Hm}$ & Qz \\
\hline & $\mathrm{Bw}_{1}$ & $\mathrm{Ct}, \mathrm{Gb}, \mathrm{Il}$ & $\mathrm{Qz}, \mathrm{Ct}, \mathrm{Gb}$ & Qz \\
\hline
\end{tabular}

Qz-Quartz, Ct-Kaolinite, Es-Smectite, Fs-Feldspar, Mi-Mica, Pg-Plagioclase, Af-Amphiboles, Px-Piroxene, Il-Illite, Bt-Biotite, Ac-Actinolite, Cl-Chlorite, Zl-Zeolite, Hb-Hornblendite, Ru-Rutile, Gb-Gibbsite, Gt-Goethite; Hm-Hematite, Mg-Manganite, Cn-Corundum. 
Table 3. Maximum phosphate adsorption capacity for the soils studied.

\begin{tabular}{|c|c|c|c|c|}
\hline Soil & Horizon & Clay $\mathrm{g} \cdot \mathrm{kg}^{-1}$ & P-remaining $\mathrm{mg} \cdot \mathrm{L}^{-1}$ & MAPC $\mathrm{mg} \cdot \mathrm{kg}^{-1}$ \\
\hline \multirow{2}{*}{$\mathrm{NVe}$} & Ap & 520 & 39.8 & 439.0 \\
\hline & Bnit. & 640 & 4.2 & 1280.0 \\
\hline \multirow{2}{*}{ MEo } & Ap & 280 & 50.2 & 353.0 \\
\hline & Bnit. & 370 & 36.2 & 475.0 \\
\hline \multirow{2}{*}{ CXbe } & Ap & 320 & 43.3 & 409.0 \\
\hline & $\mathrm{Bi}_{2}$ & 470 & 29.5 & 551.0 \\
\hline \multirow{2}{*}{ MEov } & Ap & 290 & 47.9 & 370.0 \\
\hline & $\mathrm{Bi}_{2}$ & 290 & 46.9 & 378.0 \\
\hline \multirow{2}{*}{ CXbe } & Ap & 350 & 40.7 & 431.0 \\
\hline & $\mathrm{Bi}_{2}$ & 380 & 37.7 & 460.0 \\
\hline \multirow{2}{*}{ LVAdf } & Ap & 650 & 19.8 & 701.0 \\
\hline & $\mathrm{Bw}_{1}$ & 700 & 6.6 & 1111.0 \\
\hline
\end{tabular}

Nve-Red nitosol, MEo-Orthic ebanic chernosol, Cxbe-Tb eutrophic haplic cambisol, MEov-vertic orthic ebanic chernosol LVAdf-distrophic red latosol.

tions between $\mathrm{P}$ and goethite and $\mathrm{P}$ and kaolinite. High iron-sesquioxides contents are often considered as the determining factor of $\mathrm{P}$ adsorption in soils [31]; however, the low crystalline forms should fix more $\mathrm{P}$ than the crystalline forms [30]. The differences in behavior observed for LVAdf was more related to the presence of gibbsite than to the presence of the low crystalline forms, considering the low $\mathrm{Fe}_{\mathrm{o}} / \mathrm{Fe}_{\mathrm{d}}$ ratio presented by this soil (Table 4).

The MPAC values (Table 3) ranged from 353 to $701 \mathrm{mg} \cdot \mathrm{kg}^{-1}$ in the surface horizons and from 378 to 1280 $\mathrm{mg} \cdot \mathrm{kg}^{-1}$ for the sub-surface horizons. Except for the values obtained in the MEov profile and the MEo surface layer, the rest of the soils were in the range of MPAC values as indicated by Novais and Smyth [32] for Cerrado Latosols. In Amazon soils, Lima et al. [26] reported MPAC values ranging from 210 to $2170 \mathrm{mg} \cdot \mathrm{kg}^{-1}$ in Oxisol, while Singh et al. [33] obtained values between 160 and $980 \mathrm{mg} \cdot \mathrm{kg}^{-1} \mathrm{P}$. For central Amazon, Falcão and Silva [34] reported MPAC ranging from 298 to $888 \mathrm{mg} \cdot \mathrm{kg}^{-1}$ for Ultisols. The MPAC values were lower than those normally found in highly weathered soils. In basalt-derived soils, Oxisol and Alfisol, Bognola [35] found MPAC values between 1620 and $2740 \mathrm{mg} \cdot \mathrm{kg}^{-1}$, while Valladares et al. [36] obtained values between 526 and 1.667 $\mathrm{mg} \cdot \mathrm{kg}^{-1}$ for Ultisols. Soils originating from this material have higher MPAC because of the higher clay content and occurrence of oxides such as hematite and goethite [37] [38]. Despite the parental materials, climate and relief contributed to the soil formation with high smectite contents in undulated relief, highly weathered rich Fe and $\mathrm{Al}$ oxides contents. The structure, chemical compositions, exchangeable ion type and small crystal size of smectite clays are responsible for the unique properties, including a large chemically active surface area, a high cation exchange capacity and low anion exchange capacity.

In the high clay soils (Table 3 ), phosphate adsorption was more pronounced. The Yellow Red Latosol (Oxisol) presented the greatest MPAC in the two horizons, which can be explained by the high clay content, high $\mathrm{Fe}_{\mathrm{d}}$ and low $\mathrm{Fe}_{\mathrm{c}}$ contents (Table 4). The Nitosol also presented high MPAC, greater than LVAdf, in the subsurface horizon, which can be due to the high clay content. Vertic Orthic Ebanic Chernosol had the least adsorbed P in the two horizons, which can be explained by the low clay contents and low $\mathrm{Fe}_{\mathrm{d}}$ and $\mathrm{Fe}_{\mathrm{c}}$ values. Generally the soils showed increase in $\mathrm{P}$ adsorption with increase in soil depth, which can be attributed to increase in the clay contents from horizon A to horizon B. The high phosphate adsorption in the Latosol and Nitosol in the Amazon soils can be attributed to the low Fe contents predominate in this environment [6].

The clay, $\mathrm{Fe}_{\mathrm{d}}$ and $\mathrm{Fe}_{\mathrm{c}}$ contents correlated positively and significantly with the MPAC, suggesting that these attributes contributed to an increase in the MPAC in the horizons and profiles studied (Table 5). Given the strict correlations between MPAC and clay, $\mathrm{Fe}_{\mathrm{d}}$ and $\mathrm{Fe}_{\mathrm{c}}$ contents, it can be postulated that the presence of goethite in all the soils was a major determinant for the MPAC and not kaolinite soils. Bahia Filho et al. [39] tested the effects of the mineralogical components on MPAC and observed that goethite (Gt) was mainly responsible, con- 
Table 4. Soil iron and silicon dioxide contents of soils.

\begin{tabular}{|c|c|c|c|c|c|c|}
\hline \multirow{2}{*}{ Soil } & \multirow{2}{*}{ Hor. } & $\mathrm{Fe}_{\mathrm{d}}$ & $\mathrm{Fe}_{\mathrm{o}}$ & $\mathrm{Fe}_{\mathrm{o}} / \mathrm{Fe}_{\mathrm{d}}$ & $\mathrm{Fe}_{\mathrm{c}}$ & $\mathrm{SiO}_{2}$ \\
\hline & & \multicolumn{5}{|c|}{$\mathrm{g} \cdot \mathrm{kg}^{-1}$} \\
\hline \multirow{2}{*}{$\mathrm{NVe}$} & Ap & 58.3 & 3.5 & 0.06 & 54.8 & 1.41 \\
\hline & Bnit & 75.5 & 3.2 & 0.04 & 72.3 & 1.13 \\
\hline \multirow{2}{*}{ MEo } & Ap & 106.0 & 7.7 & 0.07 & 98.3 & 1.26 \\
\hline & Bnit & 95.1 & 5.6 & 0.06 & 86.9 & 1.90 \\
\hline \multirow{2}{*}{ CXbe } & Ap & 52.0 & 6.4 & 0.12 & 45.6 & 2.01 \\
\hline & $\mathrm{Bi}_{2}$ & 51.1 & 4.9 & 0.10 & 46.2 & 2.65 \\
\hline \multirow{2}{*}{ MEov } & Ap & 34.9 & 7.7 & 0.22 & 27.2 & 2.01 \\
\hline & $\mathrm{Bi}_{2}$ & 29.4 & 1.6 & 0.05 & 27.8 & 1.37 \\
\hline \multirow{2}{*}{ CXbe } & Ap & 77.1 & 7.2 & 0.09 & 69.9 & 1.61 \\
\hline & $\mathrm{Bi}_{2}$ & 64.8 & 2.5 & 0.04 & 62.3 & 2.03 \\
\hline \multirow{2}{*}{ LVAdf } & A & 180.3 & 1.8 & 0.01 & 178.9 & 0.73 \\
\hline & $\mathrm{Bw}$ & 258.7 & 1.0 & 0.004 & 257.7 & 0.88 \\
\hline
\end{tabular}

Nve-Red nitosol, MEo-Orthic ebanic chernosol, Cxbe-Tb eutrophic haplic cambisol, MEov-vertico orthic ebanic chernosol, LVAdf-distrophic red yellow latosol. $\mathrm{Fe}_{\mathrm{d}}$-Dithionite-extracted $\mathrm{Fe}$. $\mathrm{Fe}_{\mathrm{o}}$-Oxalate-extracted iron. $\mathrm{Fe}_{\mathrm{c}}$-crystalline $\mathrm{Fe}$.

Table 5. Simple correlations between maximum phosphate adsorption capacity of soils and some soils properties.

\begin{tabular}{ccc}
\hline & A Horizon & B Horizon \\
\hline Clay & $0.79^{*}$ & $0.94^{* *}$ \\
$\mathrm{~T}$ & $-0.87^{*}$ & $-0.79^{*}$ \\
$\mathrm{C}$ & $0.38^{\text {n.s. }}$ & $0.54^{\text {n.s. }}$ \\
$\mathrm{Fe}_{\mathrm{d}}$ & $0.83^{*}$ & $0.93^{* *}$ \\
$\mathrm{Fe}_{\mathrm{o}}$ & $-0.87^{*}$ & $-0.62^{*}$ \\
$\mathrm{Fe}_{\mathrm{c}}$ & $0.84^{*}$ & $0.94^{* *}$ \\
\hline
\end{tabular}

T-Clay. $\mathrm{Fe}_{\mathrm{d}}$-Dithionite-extracted Fe. $\mathrm{Fe}_{\mathrm{o}}$-Oxalate-extracted iron. $\mathrm{Fe}_{\mathrm{c}}$-crystalline Fe. n.s.-not significant. ${ }^{*}$ mean of $0.01<$ probability $<0.05$; ${ }^{* *}$ significant at probability $<0.01$.

tributing $6 \%$ of the total MPAC. The high affinity of geothite soils for $\mathrm{P}$ is likely due to the easy access of surface phosphate anions. The $\mathrm{H}_{2} \mathrm{PO}_{4}^{-}$occupies site of the hydroxides $\left(\mathrm{OH}^{-}\right)$previously coordinated to $\mathrm{Fe}^{3+}$, forming much more stable surface complexes.

The correlation between the soil organic $\mathrm{C}$ and MPAC was not significant for the soils studied. This might be because organic $\mathrm{C}$ can influence $\mathrm{P}$ adsorption positively in numerous ways [40], negatively [41] or no effect [42]. The latter has been observed in Cerrado ecosystem (Savanna) soils where the C stock increases linearly with the soil clay and silt contents, demonstrating that total $\mathrm{C}$ does not increase the $\mathrm{P}$ adsorption, but enhances the richness of the minerals that retain $\mathrm{P}$.

The CEC values and $\mathrm{Fe}_{\mathrm{o}}$ correlated significantly and negatively, respectively, with MPAC. Indeed P adsorption tends to diminish with increase in CEC in the soils, because the negative charges repel the phosphate ion. On the other hand, negative correlation of MPAC with $\mathrm{Fe}_{\mathrm{o}}$ is in line with reported studies. Hernández and Meurer [43] studied three forms of soils in Uruguay, an Argiudoll, a Hapludert, and a Natraqualf, and observed positive correlations between $\mathrm{P}$ adsorption and low $\mathrm{Fe}$ crystalline forms $\left(\mathrm{Fe}_{\mathrm{o}}\right)$.

\section{Conclusion}

The Oxisol and the Alfisol soils presented the highest phosphate adsorption values, due to $\mathrm{Fe}$ and $\mathrm{Al}$ oxides rich minerals. The Molissol soils showed the lowest adsorption values due to the high presence of smectite clay. The 
soils that showed positive correlations with MPAC were in the order: A Horizon- $\mathrm{Fe}_{\mathrm{c}}>\mathrm{Fe}_{\mathrm{d}}>$ clay and B Horizon-clay $=\mathrm{Fe}_{\mathrm{c}}>\mathrm{Fe}_{\mathrm{d}}$. The soils of the northern border of the Amazon exhibit $\mathrm{P}$ adsorption behavior different from other areas of the Amazon. Sustaining agricultural production in these soils will require management approaches that will enhance $\mathrm{P}$ availability. An adequate pool of labile $\mathrm{P}$ in these soils could be enhanced with inorganic $\mathrm{P}$ fertilizations and other organic residues.

\section{References}

[1] Schaefer, C.E.R. and Dalrymple, J. (1996) Pedogenesis and Relict Properties of Soils with Columnar Structure from Roraima, North Amazonia. Geoderma, 71, 1-17. http://dx.doi.org/10.1016/0016-7061(95)00073-9

[2] Benedetti, U.G., Vale Jr., J.F., Schaefer, C.E.G.R., Melo, V.F. and Uchôa, S.C.P. (2011) Genesis, Chemistry and Mineralogy of Soils Derived from Plio-Plestocene Sediments and from Volcanic Rocks in Roraima-North Amazonia. Brazilian Journal of Soil Science, 35, 299-312.

[3] Melo, V.F., Schaefer, C.E.G.R. and Uchôa, S.C.P. (2010) Indian Land Use in the Raposa-Serra do Sol Reserve, Roraima, Amazonia, Brazil: Physical and Chemical Attributes of a Soil Catena Developed from Mafic Rocks under Shifting Cultivation. Catena, 80, 95-105. http://dx.doi.org/10.1016/j.catena.2009.09.004

[4] Schaefer, C.E.G.R., Resende, S.B., Correia, G.F. and Lani, J.L. (1993) Chemical and Minerological Characteristics of Sodium-Afected Soils from Northeeastern Roraima. Brazilian Journal of Soil Science, 17, 431-438.

[5] Vale Jr., J.F. (2000) Pedogenesis and Changing of Soil under Shifting Cultivation in Areas of Acid and Basic Volcanic Rocks in Northeastern Roraima. Ph.D. Thesis, Universidade Federal de Viçoa, Viçosa.

[6] Melo, V.F., Schaefer, C.E.G.R., Fontes, L.E.F., Chagas, A.C., Lemos Jr., J.B. and Andrade, R.P. (2006) Physical Chemical and Mineralogical Characteristics of Soils from the Agricultural Colony of Apiaú (Roraima, Amazonia), under Different Land Uses and after Burning. Brazilian Journal of Soil Science, 30, 1039-1050.

[7] Melo, V.F. (2002) Soil and Indicators of Agricultural Use in Roraima: Indigenous Areas of Maloca Flechal and Colonization of Apiaú. Ph.D. Thesis, Universidade Federal de Viçoa, Viçosa.

[8] Brennan, R.F., Bolland, M.D.A., Jeffery, R.C. and Allen, D.G. (1994) Phosphorus Adsorption by a Range of Western Australian Soils Related to Soil Properties. Communications in Soil Science and Plant Analysis, 25, 2785-2795. http://dx.doi.org/10.1080/00103629409369225

[9] Motta, P.E.F., Curi, N., Siqueira, J.O., Van Raij, B., Furtini Neto, A.E. and Lima, J.M. (2002) Adsorption and Forms of Phosphorus in Latosols: Influence of Mineralogy and Use. Brazilian Journal of Soil Science, 26, 349-359.

[10] Moreira, F.L.M., Mota, F.O.B., Clemente, C.A., Azevedo, B.M. and Bomfim, G.V. (2006) Phosphorus Adsorption in Ceará State Soils, Brazil. Revista Ciência Agronômica, 37, 7-12.

[11] Bahia Filho, A.F.C., Braga, J.M., Resende, M. and Ribeiro, A.C. (1983) Relationship between Phosphorus Adsorption and Mineralogical Components of Latosols Clay Fraction of the Central Plateau. Brazilian Journal of Soil Science, 7 , 221-226.

[12] Torrent, J., Barron, V. and Schwertmann, U. (1990) Phosphate Adsorption and Desorption by Goethites Differing in Crystal Morphology. Soil Science Society of American Journal, 54, 1007-1012. http://dx.doi.org/10.2136/sssaj1990.03615995005400040012x

[13] Ruan, H.D. and Gilkes, R.J. (1996) Kinetics of Phosphate Sorption and Desorption by Synthetic Aluminous Goethite before and after Thermal Transformation to Hematite. Clay Minerals, 31, 63-74. http://dx.doi.org/10.1180/claymin.1996.031.1.06

[14] Bedin, I., Furtini Neto, A.E., Resende, A.V., Faquin, V., Tokura, A.M. and Santos, J.Z.L. (2003) Phosphate Fertilizers and Soybean Production in Soils with Different Phosphate Buffer Capacities. Brazilian Journal of Soil Science, 27, 639-646.

[15] Santos, R.D., Lemos, R.C., Santos, H.G., Ker, J.C. and Anjos, L.H. (2005) Description Handbook and Collecting of Soil in Field. 5 Edition, Sociedade Brasileira de Ciência do Solo, Viçosa, MG.

[16] Embrapa (Empresa Brasileira de Pesquisa Agropecuaria) (2006) Brazilian System of Soil Classification. 2nd Edition, Embrapa Solos, Rio de Janeiro.

[17] Embrapa (Empresa Brasileira de Pesquisa Agropecuaria) (1997) Manual of Soil Analysis Methods. 2nd Edition, National Soil Research Center, Rio de Janeiro.

[18] Mckeague, J.A. and Day, J.H. (1966) Dithionite and Oxalate Extractable Fe and Al as Aids in Differentiating Various Classes of Soils. Canadian Journal of Soil Science, 46, 13-22. http://dx.doi.org/10.4141/cjss66-003

[19] Mehra, O.P. and Jackson, M.L. (1960) Iron Oxide Removal from Soils and Clay by a Dithionite-Citrate System Buffered 
with Sodium Bicarbonate. Clays and Clay Minerals, 7, 317-327. http://dx.doi.org/10.1346/CCMN.1958.0070122

[20] Whittig, L.D. and Allardice, W.R. (1986) X-Ray Diffraction Techniques. In: Klute, A., Ed., Methods of Soil Analysis, Part 1: Physical and Mineralogical Methods, American Society of Agronomy, Madison, 331-362.

[21] Chen, P.-Y. (1977) Table of Key by Lines in X-Ray Power Diffraction Patterns of Minerals in Clays and Associated Rocks. Occasional Paper 21, Department of Natural Resources, Geological Survey, Bloomington, 67 p.

[22] Alvarez, V.V.H. and Fonseca, D.M. (1990) Definition of Doses of Phosphorus to Determine the Maximum Adsorption Capacity for Phosphate in Greenhouse Trials. Brazilian Journal of Soil Science, 14, 49-55.

[23] Murphy, J. and Riley, J.P. (1962) A Modified Single Solution Method for the Determination of Phosphate in Natural Waters. Analytica Chimica Acta, 27, 31-36. http://dx.doi.org/10.1016/S0003-2670(00)88444-5

[24] Bera, R., Seal, A., Bhattacharyya, P., Mukhopadhyay, K. and Giri, R. (2006) Phosphate Sorption Desorption Characteristics of Some Ferruginous Soils of Tropical Region in Eastern India. Environmental Geology, 51, 399-407. http://dx.doi.org/10.1007/s00254-006-0335-9

[25] Silva, J.R.T. (1999) Soils of Acre: Physical, Chemical and Mineralogical and Phosphate Adsorption. Thesis of Ph.D., Federal Universtiy of Viçosa, MG, Brazil.

[26] Lima, H.N., Melo, J.W.V., Schaefer, C.E.G.R., Ker, J.C. and Lima, A.M.N. (2006) Mineralogy and Chemistry of Three Soils along a Toposequence from the Upper Solimões Basin, Western Amazonia. Brazilian Journal of Soil Science, $\mathbf{3 0}$, 59-68.

[27] Schaefer, C.E.G.R. (1994) Soils and Paleosols from Northeast Roraima, North Amazonia: Geomorphology, Genesis and Landscape Evolution. Ph.D. Dissertation, University of Reading, Reading, Berkshire.

[28] Schaefer, C.E.G.R. and Vale Júnior, J.F. (1997) Climate Changing and Landscape Evolution in Roraima: A Review from Cretaceous to Recent. In: Barbosa, R.I., Ferreira, E.J.G. and Castellón, E.G., Eds., Man, Environment and Ecology in the State of Roraima, INPA, Manaus, 231-293.

[29] Alvarez, V.V.H., Novais, R.F., Dias, L.E. and Oliveira, J.A. (2000) Determination and Use of the Remaining Phosphorus. Newsletter, Sociedade Brasileira de Ciência do Solo, 25, 27-33.

[30] Alves, M.E. and Lavorenti, A. (2004) Remaining Phosphorus and Sodium Fluoride pH in Soils with Different Clay Contents and Clay Mineralogies. Pesquisa Agropecuária Brasileira, 39, 241-246. http://dx.doi.org/10.1590/S0100-204X2004000300006

[31] Uehara, G. and Gillman, G. (1981) The Mineralogy, Chemistry and Physics of Tropical Soils with Variable Charge Clays. Westview, Boulder.

[32] Novais, R.F. and Smyth, T.J. (1999) Phosphorus in Soil and Plant in Tropical Conditions. Universidade Federal de Viçosa-MG, Viçosa, 399 p.

[33] Singh, R., Moller, M.R.F. and Ferreira, W.A. (1983) Phosphorus Adsorption Kinetics in Amazonian Soils. Revista Brasileira de Ciência do Solo, 7, 227-231.

[34] Falcão, N.P. and Silva, J.R.A. (2003) Phosphorus Adsorption Characteristics in Some Central Amazonian Soils. Acta Amazônica, 34, 337-342. http://dx.doi.org/10.1590/S0044-59672004000300001

[35] Bognola, I.A. (1995) Chemical, Physical and Mineralogical Soil Intermediaries between Latosols Brunos and Latosols Purple. Master's Thesis, Universidade Federal de Viçosa, Viçosa.

[36] Valladares, G.S., Pereira, M.G. and Anjos, L.H.C. (2003) Phosphate Sorption in Low Activity Clay Soils. Bragantia, 62, 111-118. http://dx.doi.org/10.1590/S0006-87052003000100014

[37] Curi, N., Camargo, O.A., Guedes, G.A.A. and Silveira, J.V. (1988) Phosphorus Sorption in Latosols of Southeast and South of Brazil. In: Reunião de Classificação e Correlação de Solos e Interpretação de Aptidão Agrícola, 3rd Edition, Empresa Brasileira de Pesquisa Agropecuária, Rio de Janeiro, 150.

[38] Fontes, M.P.F. and Weed, S.B. (1996) Phosphate Adsorption by Clays from Brazilian Oxisols: Relationships Whit Specific Surface Area and Mineralogy. Geoderma, 72, 37-51. http://dx.doi.org/10.1016/0016-7061(96)00010-9

[39] Bahia Filho, A.F.C., Vasconcellos, C.A., Santos, H.L., Mendes, J.F., Pitta, G.V.E. and Oliveira, A.C. (1982) Inorganic Phosphorus and Available Phosphorus Forms in a Dark Red Latosol, Fertilized with Different Phosphates. Brazilian Journal of Soil Science, 6, 99-104.

[40] Parfitt, R.L. (1978) Anion Adsorption by Soils and Soil Materials. Advances in Agronomy, 30, 1-50. http://dx.doi.org/10.1016/S0065-2113(08)60702-6

[41] Borggaard, O.K., Jorgensen, S.S., Moberg, J.P. and Raben-Lage, B. (1990) Influence of Organic Matter on Phosphate Adsorption by Aluminum and Iron Oxides in Sandy Soils. European Journal of Soil Science, 41, 443-449. http://dx.doi.org/10.1111/j.1365-2389.1990.tb00078.x

[42] Zinn, Y.L., Lal, R. and Resck, D.V.S. (2005) Texture and Organic Carbon Relations Described by a Profile Pedotrans- 
fer Function for Brazilian Cerrado Soils. Geoderma, 127, 168-173. http://dx.doi.org/10.1016/j.geoderma.2005.02.010

[43] Hernández, J. and Meurer, E.J. (1990) Phosphorus Sorption in Soils from Uruguay and Its Relationship with Iron Oxides. Brazilian Journal of Soil Science, 22, 223-230. 